\title{
Implementasi Pengendali Logika Fuzzy pada Navigasi Robot Penjejak Dinding
}

\author{
Gunawan Dewantoro ${ }^{1}$, Deddy Susilo ${ }^{2}$, Prabata Pideksa Adi $^{3}$
}

\begin{abstract}
Navigation is one of the important issues when designing autonomous robot. PID-based control methods have some difficulties in dealing with uncertain and nonlinear plants. The advantages of fuzzy logic as a control method compared to the conventional controllers are flexible and straightforward for complex systems. Upon implementing fuzzy logic based control method, the robots are supposed to navigate autonomously and track along the maze in various configurations effectively and efficiently. The maze used in this study is adopted from the rule of Trinity College Fire-Fighting Home Robot (TCFFHR) Contest 2016. The embedded processor utilized in this study is ATMega 128. The principal sensors are Sonar Range Finders (SRFs), supported with line sensors and infrared sensors. The experiments show that fuzzy logic controller gives less contact per turn ratio compared to Proportional-Derivative controller and hence is very effective to deal with various environment situations while navigating.
\end{abstract}

Intisari- Navigasi merupakan salah satu kendala utama dalam perancangan robot otomatis. Metode kontrol berbasis PID yang popular dipakai menemui sejumah kendala pada sistem yang tidak pasti dan nonlinier. Keunggulan logika fuzzy sebagai metode kontrol dibandingkan kontroler konvensional adalah fleksibilitas dan kemudahan perancangan untuk sistem yang kompleks. Pada penerapan metode kontrol logika fuzzy, robot dirancang agar mampu bernavigasi secara otomatis dan dapat menelusuri peta lapangan pengujian dengan segala kondisi serta variasi secara efektif dan efisien. Peta lapangan yang digunakan sebagai pengujian adalah peta lapangan yang digunakan dalam Trinity College Fire-Fighting Home Robot (TCFFHR) Contest 2016. Untuk perangkat pemroses robot memakai mikrokontroller tipe ATMega128. Robot ini memakai sensor Sonar Range Finder (SRF) sebagai sensor utama serta menggunakan sensor infrared dan sensor garis. Dari hasil pengujian robot yang menggunakan metode kontrol fuzzy mampu bernavigasi dengan rasio kontak per putaran yang lebih baik dibandingkan metode kontrol Propotional-Derivative dan sangat efektif dalam menghadapi berbagai situasi lingkungan yang terjadi ketika bernavigasi.

Kata Kunci- kontroler logika fuzzy, navigasi, robot penjejak dinding.

\footnotetext{
1.2 Dosen, Prodi Teknik Elektro Universitas Kristen Satya Wacana, Jl. Diponegoro 52-60 Salatiga 50711 Indonesia (tlp: 0298-321212; fax: 0298-321212; e-mail: gunawan.dewantoro@staff.uksw.edul, deddy.susilo@ymail.com ${ }^{2}$ )

${ }^{3}$ Mahasiswa, Prodi Teknik Elektro Universitas Kristen Satya Wacana, Jl. Diponegoro 52-60 Salatiga 50711 Indonesia (tlp: 0298-321212; fax: 0298-321212; e-mail: prabataadi@gmail.com)
}

\section{PENDAHULUAN}

Perkembangan teknologi robot berkembang dengan pesat dewasa ini. Robot telah masuk dalam berbagai segi kehidupan manusia, mulai dari robot rumah tangga sampai dalam dunia industri.

Para peneliti dari seluruh belahan dunia saat ini berlomba untuk mendesain robot, agar mampu melaksanakan berbagai tugas membantu pekerjaan manusia. Salah satu upaya pemerintah Indonesia sendiri mendorong perkembangan robot adalah dengan menyelenggarakan Kontes Robot Pemadam Api Indonesia (KRPAI). Dalam kontes ini robot dituntut untuk dapat bermanuver didalam lingkungan asing disertai rintangan, untuk dapat menemukan titik api.

Untuk membangun sebuah robot otomatis, navigasi merupakan salah satu masalah utama yang akan dihadapi para perancang. Saat ini terdapat banyak metode kontrol yang dapat digunakan. Pengendali berbasis logika fuzzy merupakan metode pengendali yang termasuk golongan Artificial Intelligence. Tidak seperti pengendali konvensional misalnya kendali Proportional-Integral-Derivative (PID) yang hanya menggunakan perhitungan matematis, pengendali berbasis logika fuzzy menggabungkan perhitungan matematis dan juga algoritma untuk mengendalikan perilaku robot terhadap dinamika lingkungan.

Sebagian besar dari metode kontrol yang saat ini digunakan masih berbasis PID. Dalam kenyataanya metode kontrol berbasis PID tersebut menemui sejumlah kendala antara lain model matematis yang tidak mencerminkan keadaan sesungguhnya [1]. Dalam metode PID, pemodelan sistem sangatlah penting. Melalui pemodelan dapat diketahui karakteristik sistem serta berguna dalam proses penalaan PID. Namun dalam praktiknya model matematis sistem sulit untuk dihasilkan karena beberapa kendala antara lain sering kali perancang menemui fenomena yang kurang dimengerti terjadi di dalam sistem, pemilihan parameter yang kurang akurat, dan kompleksitas sistem yang dimodelkan. Walaupun model matematis pada akhirnya didapatkan seringkali para peneliti menghadapi model matematis yang kompleks serta sulit diaplikasikan dalam alat karena keterbatasan pemroses. Cara lain yang dapat diambil adalah menyederhanakan sistem dengan mengabaikan aspek-aspek tertentu karena diasumsikan pada kondisi ideal.

Selain itu model kontrol berbasis PID tidak handal pada sistem yang tidak linier [2]. Dalam robot gaya gesek pada roda dan motor adalah salah satu aspek yang menyebabkan sistem tidak linier. Gaya gesek ini sulit untuk diprediksi dan sangat bervarisasi pada beban robot itu sendiri. Pada perilaku sistem yang tidak linier sulit untuk melakukan penalaan PID. Pengendali berbasis fuzzy merupakan pengendali non- 
analytical [3]. Kehandalan metode fuzzy tidak bergantung pada model matematis sistem yang dikendalikan namun bergantung pada kegiatan percobaan dan juga pengalaman yang dimiliki perancang. Metode kontrol berbasis fuzzy juga menjadi salah satu alternatif dalam menghadapi sistem yang tidak linier. Dalam memproses setiap masukan dari lingkungan, metode fuzzy menggunakan range-to-point control. Setiap parameter (input/output) diklasifikasikan dalam variabel linguistik. Nilai input dari sensor dalam bentuk variabel linguistik ini akan di proses di dalam aturan kontrol yang dibuat perancang untuk menentukan nilai output yang sesuai. Aturan kontrol inilah yang menjadi kekuatan metode fuzzy dalam menghadapi sistem yang tidak linier.

Dalam banyak penelitian model sistem berbasis fuzzy lebih handal daripada model sistem berbasis PID [4],[5]. Pengendali berbasis fuzzy memiliki overshoot yang rendah dan error yang kecil dibandingkan pengendali berbasis PD ataupun PID. Dalam penelitian [6],[7] juga menunjukkan bahwa metode kontrol berbasis logika fuzzy juga dapat bekerja secara adaptif sehingga dapat menyesuaikan dengan keadaan input yang selalu mengalami perubahan.

Dakam artikel ini kami mengimplementasikan kendali logika fuzzy pada robot beroda. Salah satu faktor penting dalam keberhasilan robot menjalankan tugasnya adalah navigasi. Berbeda dengan penelitian sebelumnya, penelitian ini mencoba untuk mengklasifikasikan error pada proses fuzzifikasi di mana sensor infrared dan sensor garis ditambahkan untuk melengkapi nilai klasifikasi. Selain itu, input yang digunakan tidak menggunakan perubahan error, melainkan error pada SRF kanan, kiri dan depan. Kelebihan dari logika fuzzy ini adalah pengendali bekerja range-to-point di mana rentang data tertentu akan diolah secara matematis serta digabungkan dengan algoritma tertentu (metode if-then) yang dibuat dalam aturan kontrol (rule base). Prosesor ATmega 128 digunakan untuk mengeksekusi semua perintah meliputi akuisisi data, fuzzifikasi, inferensi, defuzzifikasi, dan menggerakkan aktuator. Prosesor ini sengaja dipilih karena memiliki kapasitas memory yang memadai untuk pengaksesan data menggunakan linked-list. Dengan mengetahui rentang data pembacaan sensor pada objek di lapangan pertandingan, penggunaan logika fuzzy sebagai basis kontrol akan lebih handal selama melakukan navigasi.

\section{PERANCANGAN}

Sebagaimana sebuah robot dirancang, bagian robot umumya terdiri dari perangkat keras dan perangkat lunak. Titik berat penelitian ini adalah pada pengembangan dan evaluasi kinerja perangkat lunak khususnya metode navigasi robot. Meskipun demikian, bagian perangkat keras robot tetap akan dibahas secara ringkas untuk memberikan pemahaman yang lebih utuh.

\section{A. Perangkat Keras Robot}

Perangkat pemroses utama robot menggunakan mikrokontroller ATMega 128 yang bertugas mengolah data sensor dan memproses logika fuzzy untuk mengontrol

Gunawan Dewantoro: Implementasi Pengendali Logika Fuzzy... pergerakan robot seperti yang ditunjukkan Gambar 1. Sensor yang digunakan pada robot ini yaitu, sensor jarak SRF, sensor infrared, dan sensor garis. Sensor jarak SRF digunakan sebagai pengukur jarak dinding dengan robot ketika robot bernavigasi menelusuri peta lapangan. Sensor infrared digunakan untuk mendeteksi objek pada titik buta robot yang tidak terjangkau oleh sensor SRF. Sedangkan sensor garis digunakan untuk membantu pergerakan robot ketika memasuki ruangan. Kerangka robot menyerupai bentuk sebuah mobil mainan, berbahan dasar plat acrylic yang memiliki 2 buah motor DC sebagai penggerak utama dengan kecepatan rotasi $200 \mathrm{rpm}$ dan memiliki torsi $1,3 \mathrm{~kg}-\mathrm{cm}$ untuk setiap motornya. Dimensi robot yang dibuat adalah $(p \times l \times t)$ $=24 \times 21 \times 27 \mathrm{~cm}$. Sedangkan berat keseluruhan robot adalah $1,375 \mathrm{~kg}$ seperti terlihat pada Gambar 2.

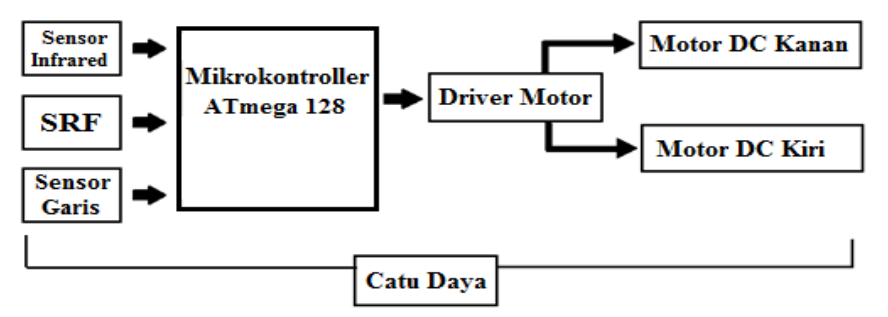

Gambar 1: Blok diagram perangkat keras robot

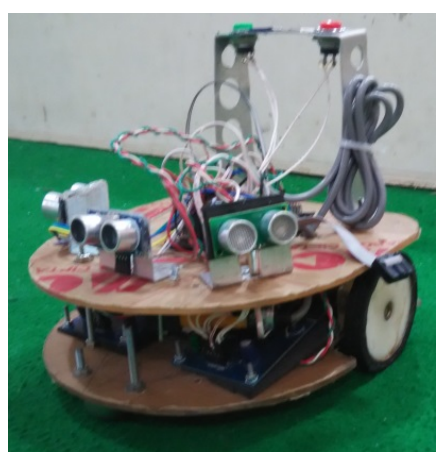

Gambar 2: Bentuk fisik robot

Untuk mengemudikan robot beroda ini digunakan jenis kemudi diferensial yang memiliki model kinematika seperti ditunjukkan Gambar 3.

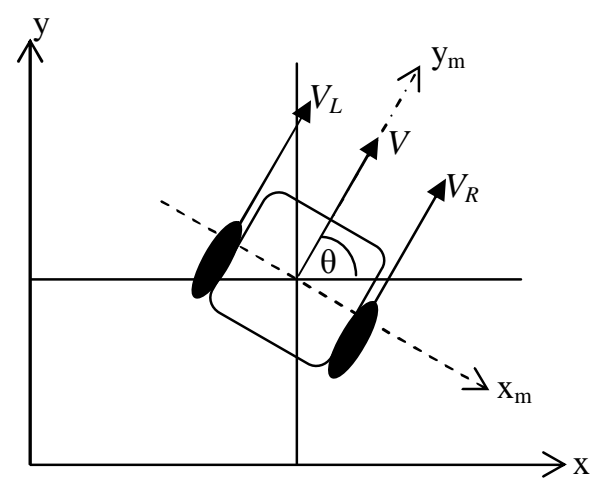

Gambar 3: Model arsitektur kemudi diferensial p-ISSN:1693 - 2951; e-ISSN: 2503-2372 
Persamaan kinematika pada model di atas adalah:

$$
\left[\begin{array}{c}
\dot{x} \\
\dot{y} \\
\dot{\theta}
\end{array}\right]=\left[\begin{array}{cc}
\cos \theta & 0 \\
\sin \theta & 0 \\
0 & 1
\end{array}\right]\left[\begin{array}{l}
v \\
\omega
\end{array}\right]
$$

di mana $\omega$ adalah kecepatan sudut robot

\section{B. Perangkat Lunak Robot}

Dalam perancangan robot penulis menggunakan metode fuzzy untuk mengendalikan robot. Dalam penerapan logika fuzzy ada beberapa tahapan yang harus dilalui untuk mengolah input data sensor sebelum akhirnya dihasilkan sinyal output ke aktuator. Gambar 4 menunjukkan tahapan pengontrolan menggunakan metode fuzzy.

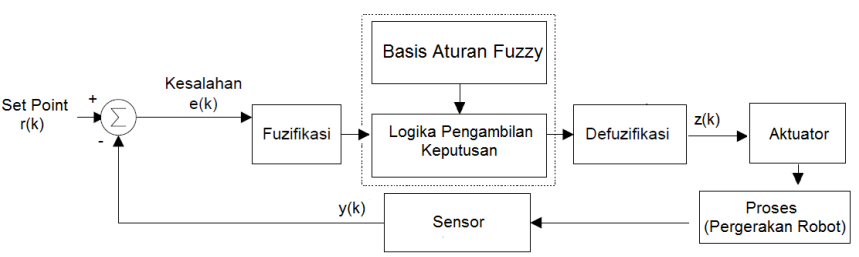

Gambar 4: Mekanisme kendali logika fuzzy kalang tertutup

di mana $r(k)$ adalah jarak yang diinginkan, $z(k)$ adalah nilai crisp proses defuzzifikasi, $y(k)$ adalah jarak aktual, dan $e(k)$ adalah selisih antara $r(k)$ dan $y(k)$. Dikarenakan metode fuzzy bekerja berdasarkan himpunan-himpunan, maka data input sensor (input error) yang basisnya berbeda-beda harus diseragamkan dengan cara klasifikasi. Hasil proses klasifikasi ini akan didapatkan data error yang akan diolah oleh logika fuzzy. Tabel I menunjukkan klasifikasi data sensor yang digunakan pada robot. Tabel I menunjukkan bahwa semakin positif hasil klasifikasi nilai sensor maka semakin jauh jarak dinding dengan badan robot, sebaliknya semakin negatif hasil nilai klasifikasi maka semakin dekat jarak dengan dinding. Nilai aktual sensor ini merupakan data numerik keluaran SRF dan tidak memiliki satuan karena masih berupa data mentah.

\section{Fuzzifikasi}

Fuzzifikasi adalah proses mentransformasikan data tegas (crisp data) masukan menjadi variabel linguistik (himpunan fuzzy), dengan derajat keanggotaan tertentu atau bisa disebut nilai fuzzy masukan. Dalam proses ini nilai fuzzy masukan yang dihasilkan dipengaruhi oleh rancangan fungsi keanggotaan input yang digunakan. Dalam penelitian ini fungsi keanggotaan input yang dirancang dan digunakan dapat dilihat pada Gambar 5 dan Gambar 6. Robot ini menggunakan tiga buah masukan yang digunakan untuk menentukan posisinya pada peta lapangan. Masing-masing nilai masukan mempunyai fungsi keanggotaannya masing-masing. Contoh penggunaan fungsi keanggotaan ini misalkan error kanan memiliki nilai tegas dari sensor senilai +6 maka hasil dari proses fuzzifikasi adalah derajat keanggotaan 0,5 (skala 0-1) untuk himpunan "Jauh" dan "Sangat Jauh". Sedangkan untuk himpunan yang lain derajat keanggotaannya adalah 0 .
TABEL I

KLASIFIKASI NILAI INPUT SENSOR

\begin{tabular}{|c|c|c|c|}
\hline \multirow{2}{*}{ Nilai Aktual Sensor (tanpa satuan) } & \multicolumn{3}{|c|}{ Nilai Klasifikasi Sensor } \\
\hline & Kiri & Depan & Kanan \\
\hline SRF $\leq$ (Setpoint-130) & -7 & -7 & -7 \\
\hline$($ Setpoint-130) $<$ SRF $\leq($ Setpoint -110$)$ & -6 & -6 & -6 \\
\hline (Setpoint -110$)<$ SRF $\leq($ Setpoint -90$)$ & -5 & -5 & -5 \\
\hline$($ Setpoint -90$)<$ SRF $\leq($ Set Point-70) & -4 & -4 & -4 \\
\hline$($ Setpoint -70$)<$ SRF $\leq$ (Set Point-50) & -3 & -3 & -3 \\
\hline (Setpoint -50$)<$ SRF $\leq($ Set Point-30) & -2 & -2 & -2 \\
\hline (Setpoint -30$)<$ SRF $\leq$ (Set Point-10) & -1 & -1 & -1 \\
\hline (Setpoint -10$)<\mathrm{SRF} \leq($ Set Point $)$ & 0 & 0 & 0 \\
\hline$($ Setpoint $)<$ SRF $\leq($ Set Point +10$)$ & 0 & 0 & 0 \\
\hline$($ Setpoint +10$)<$ SRF $\leq($ Setpoint +30$)$ & 1 & 1 & 1 \\
\hline$($ Setpoint +30$)<$ SRF $\leq($ Set Point +50$)$ & 2 & 2 & 2 \\
\hline$($ Setpoint +50$)<$ SRF $\leq($ Set Point +70$)$ & 3 & 3 & 3 \\
\hline$($ Setpoint +70$)<$ SRF $\leq($ Set Point +90$)$ & 4 & 4 & 4 \\
\hline$($ Setpoint +90$)<$ SRF $\leq($ Setpoint +110$)$ & 5 & 5 & 5 \\
\hline$($ Setpoint +110$)<\mathrm{SRF} \leq($ Setpoint +130$)$ & 6 & 6 & 6 \\
\hline$($ Setpoint +130$)<$ SRF $\leq($ Setpoint +150$)$ & 7 & 7 & 7 \\
\hline$($ Setpoint +150$)<\mathrm{SRF} \leq($ Setpoint +170$)$ & 8 & 8 & 8 \\
\hline$($ Setpoint +170$)<$ SRF $\leq($ Setpoint +190$)$ & 9 & 9 & 9 \\
\hline$($ Setpoint +190$)<$ SRF $\leq($ Setpoint +210$)$ & 10 & 10 & 10 \\
\hline$($ Setpoint +210$)<$ SRF $\leq($ Setpoint +230$)$ & 11 & 11 & 11 \\
\hline$($ Setpoint +230$)<$ SRF $\leq($ Setpoint +250$)$ & 12 & 12 & 12 \\
\hline$($ Setpoint +250$)<$ SRF $\leq($ Setpoint +270$)$ & 13 & 13 & 13 \\
\hline$($ Setpoint +270$)<$ SRF $\leq($ Setpoint +290$)$ & 14 & 14 & 14 \\
\hline$($ Setpoint +290$)<$ SRF $\leq($ Setpoint +310$)$ & 15 & 15 & 15 \\
\hline$($ Setpoint +310$)<$ SRF $\leq($ Setpoint +330$)$ & 16 & 16 & 16 \\
\hline$(\mathrm{SRF} \geq$ Set Point +330$)$ & 20 & 20 & 20 \\
\hline Sensor IR Kanan $==0$ & - & - & -7 \\
\hline Sensor IR Kiri $==0$ & -7 & - & - \\
\hline Sensor Garis Kanan $\geq 500$ & - & - & 0 \\
\hline Sensor Garis Kiri $\geq 500$ & 0 & - & - \\
\hline
\end{tabular}

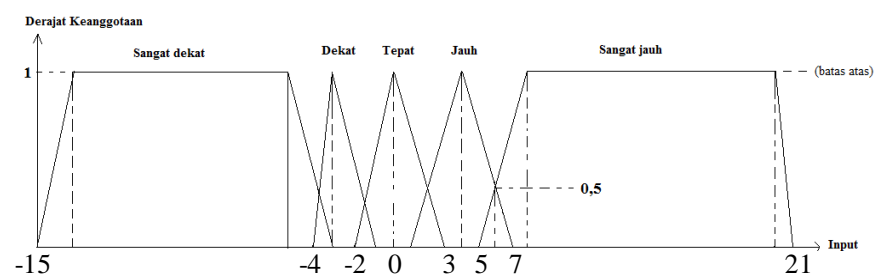

Gambar 5: Fungsi keanggotaan input error kanan dan kiri

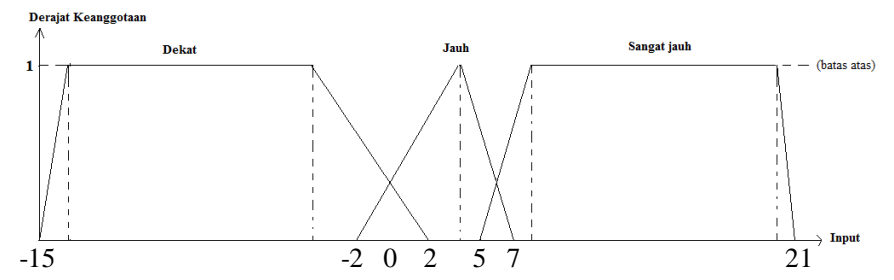

Gambar 6: Fungsi keanggotaan input error depan

Dalam perancangan robot ini digunakan dua buah fungsi fuzzy output yaitu fungsi keanggotaan keluaran Pulse Width Modulation (PWM) roda kanan dan fungsi keanggotaan output PWM roda kiri yang ditunjukkan pada Gambar 7. 
Teknologi Elektro, Vol. 16, No. 02, Mei - Agustus 2017

Sumbu mendatar merupakan sumbu PWM yaitu nilai-nilai yang digunakan untuk mengontrol kecepatan motor DC. Misal jika nilai PWM untuk memutar roda senilai 256, maka derajat keanggotaannya adalah 0,5 untuk himpunan "Cepat".

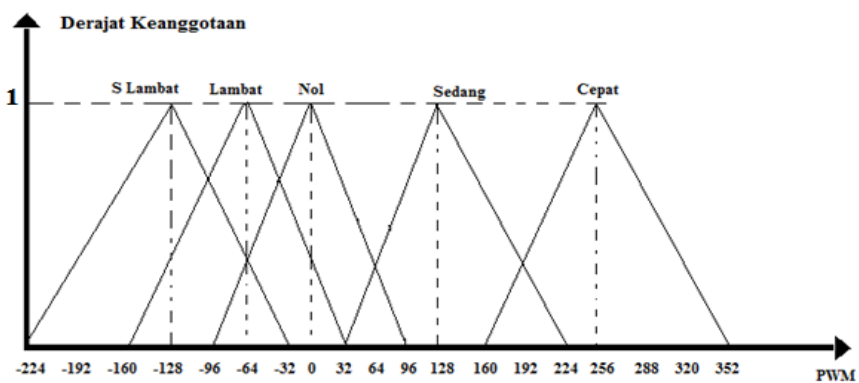

Gambar 7: Fungsi keanggotaan output PWM roda kanan dan kiri

\section{Basis aturan dan logika pengambilan keputusan}

Pada tahapan ini, sistem menalar nilai masukan untuk menentukan nilai keluaran (fuzzy output) sebagai bentuk pengambil keputusan [5]. Tahap ini mengkombinasikan fungsi keanggotaan dan basis aturan dalam menentukan keluaran fuzzy. Tiap aturan akan dievaluasi sehingga hasil penilaian dan pengambilan keputusan merupakan kumpulan atau korelasi antar aturan. Pada perancangan robot penulis menggunakan metode max-min inference dalam mengevaluasi tiap aturan fuzzy [8].

Dalam penelitian ini, basis aturan kontrol dibuat berdasarkan pengetahuan dan pengalaman perancang dalam dinamika pergerakan robot penjejak dinding. Sebuah aturan kendali fuzzy adalah aturan dalam bentuk "jika ... maka ..." (IF-THEN) seperti berikut [9]:

Aturan 1: Jika $\mathrm{x}=\mathrm{A} 1$ dan $\mathrm{y}=\mathrm{B} 1$ maka $\mathrm{z}=\mathrm{C} 1$

Aturan 2: Jika $\mathrm{x}=\mathrm{A} 2$ dan $\mathrm{y}=\mathrm{B} 2$ maka $\mathrm{z}=\mathrm{C} 2$

Aturan yang ditetapkan digunakan untuk menspesifikasikan hubungan antara himpunan fuzzy masukan dan himpunan fuzzy keluaran. Robot ini memiliki dua mode navigasi yaitu follow kanan dan kiri. Untuk follow kanan robot akan menjelajahi ruangan dengan arah berlawanan arah jarum jam sebaliknya untuk follow kiri robot akan menjelajahi ruangan searah jarum jam. Untuk follow kanan robot hanya menggunakan input error depan dan kanan. Sedangkan untuk follow kiri robot hanya menggunakan input error depan dan kiri. Tabel II, III, IV, dan V menunjukkan rancangan aturan kontrol dalam navigasi robot penjejak dinding ini.

TABEL III

TABULASI ATURAN KONTROL UNTUK RODA KANAN SAAT FOLLOW KANAN

\begin{tabular}{|c|c|c|c|}
\hline Error Kanan Depan & Dekat & Jauh & $\begin{array}{c}\text { Sangat } \\
\text { Jauh }\end{array}$ \\
\hline Sangat Dekat & Cepat & Sedang & Cepat \\
\hline Dekat & Cepat & Cepat & Cepat \\
\hline Tepat & Cepat & Sedang & Cepat \\
\hline Jauh & Cepat & Nol & Sedang \\
\hline
\end{tabular}

Gunawan Dewantoro: Implementasi Pengendali Logika Fuzzy...

\begin{tabular}{|c|c|c|c|}
\hline Sangat Jauh & Cepat & Lambat & Nol \\
\hline \multicolumn{3}{|c|}{ TABEL III } \\
Error Kanan & Dekat & Jauh & $\begin{array}{c}\text { Sangat } \\
\text { Jauh }\end{array}$ \\
\hline Sangat Dekat & S Lambat & Lambat & Lambat \\
\hline Dekat & S Lambat & Nol & Sedang \\
\hline Tepat & S Lambat & Sedang & Cepat \\
\hline Jauh & S Lambat & Cepat & Cepat \\
\hline Sangat Jauh & S Lambat & Cepat & Cepat \\
\hline
\end{tabular}

TABEL III

TABULASI ATURAN KONTROL UNTUK RODA KANAN SAAT FOLLOW KIRI

\begin{tabular}{|c|c|c|c|}
\hline Error Kiri & Dekat & Jauh & $\begin{array}{c}\text { Sangat } \\
\text { Jauh }\end{array}$ \\
\hline Sangat Dekat & S Lambat & Lambat & Lambat \\
\hline Dekat & S Lambat & Nol & Sedang \\
\hline Tepat & S Lambat & Sedang & Cepat \\
\hline Jauh & S Lambat & Cepat & Cepat \\
\hline Sangat Jauh & S Lambat & Cepat & Cepat \\
\hline
\end{tabular}

TABEL $\mathrm{V}$

TABULASI ATURAN KONTROL UNTUK RODA KIRI SAAT FOLLOW KIRI

\begin{tabular}{|c|c|c|c|}
\hline Error Kiri & Dekat & Jauh & $\begin{array}{c}\text { Sangat } \\
\text { Jauh }\end{array}$ \\
\hline Sangat Dekat & Cepat & Sedang & Cepat \\
\hline Dekat & Cepat & Cepat & Cepat \\
\hline Tepat & Cepat & Sedang & Cepat \\
\hline Jauh & Cepat & Nol & Sedang \\
\hline Sangat Jauh & Cepat & Lambat & Nol \\
\hline
\end{tabular}

Contoh kasus dalam penggunaan aturan kontrol saat follow kanan:

IF Error Kanan "Tepat" AND Error Depan "Sangat Jauh" THEN PWM Roda Kanan IS “Cepat”

\section{E. Defuzifikasi}

Proses defuzifikasi bertujuan untuk mengkonversi nilai fuzzy output kembali menjadi data keluaran tegas (crisp output) atau keluaran klasik kepada objek kontrol [2]. Dalam perancangan robot metode defuzzifikasi yang digunakan perancang adalah metode center of gravity. Metode ini dirumuskan pada (2):

$$
\mathrm{Z}_{\mathrm{COG}}=\frac{\sum_{\mathrm{j}=1}^{\mathrm{n}} \mu_{\mathrm{fo}}\left(\mathrm{Z}_{\mathrm{j}}\right) \cdot \mathrm{Z}_{\mathrm{j}}}{\sum_{\mathrm{j}=1}^{\mathrm{n}} \mu_{\mathrm{fo}}\left(\mathrm{Z}_{\mathrm{j}}\right)}
$$

Di mana $\mu_{f o}\left(Z_{i}\right)$ merepresentasikan luasan area dari fungsi himpunan yang ada pada fungsi fuzzy output dengan nilai centroid point $Z$ yang ke-j. Centroid point adalah titik tengah sumbu $x$ (sumbu mendatar) yang ada pada masing-masing himpunan pada fungsi fuzzy output.

p-ISSN:1693 - 2951; e-ISSN: 2503-2372 


\section{PENGUJIAN DAN ANALISIS}

\section{A. Pengujian Sensor SRF}

Dalam pengujian SRF ini, sensor akan diletakkan berhadapan lurus dengan diding atau objek penghalang yang cukup lebar kemudian divariasikan jaraknya pada rentang jarak $3 \mathrm{~cm}$ sampai $400 \mathrm{~cm}$. Nilai yang dicatat dalam pengujian ini adalah lamanya waktu sinyal echo saat dalam kondisi high untuk setiap variasi jarak. Pengujian dilakukan menggunakan timer mikrokontroler dengan frekuensi 172,8 kHz. Dari pengujian ini, nilai SRF cukup linier dengan rata-rata untuk kenaikan $1 \mathrm{~cm}$ maka nilai timer naik 10,2 poin seperti ditunjukkan Tabel VI.

TABEL VI

HASIL PENGUJIAN SRF

\begin{tabular}{|c|c|}
\hline Jarak Dari Tembok & Nilai Timer \\
\hline $400 \mathrm{~cm}$ & 4136 \\
\hline $300 \mathrm{~cm}$ & 3025 \\
\hline $200 \mathrm{~cm}$ & 2038 \\
\hline $100 \mathrm{~cm}$ & 1014 \\
\hline $60 \mathrm{~cm}$ & 606 \\
\hline $50 \mathrm{~cm}$ & 503 \\
\hline $40 \mathrm{~cm}$ & 404 \\
\hline $30 \mathrm{~cm}$ & 302 \\
\hline $20 \mathrm{~cm}$ & 206 \\
\hline $10 \mathrm{~cm}$ & 108 \\
\hline $3 \mathrm{~cm}$ & 40 \\
\hline
\end{tabular}

\section{B. Pengujian Navigasi Follow Kanan dan Follow Kiri}

Dalam pengujian ini robot akan bernavigasi mengelilingi peta lapangan selama 3 menit. Percobaan dilakukan sebanyak 60 kali untuk masing masing mode navigasi dan dilakukan pada peta TCFFHR 2016 seperti ditunjukkan Gambar 8.

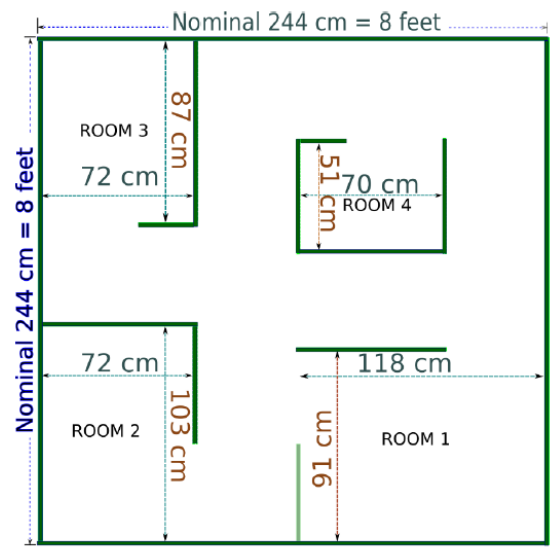

Gambar 8: Bentuk dan ukuran lapangan pengujian

Selama robot menjelajahi peta terdapat beberapa parameter sebagai acuan keberhasilan navigasi. Berikut penjabarannya :

1. Jumlah kontak dengan dinding selama 3 menit (K)

Ketika bernavigasi, robot diharapkan untuk tidak melakukan kontak dengan dinding. Semakin sedikit kontak dengan dinding, maka kehandalan navigasi robot semakin baik.
2. Jumlah kontak dengan dinding yang panjang goresan lebih dari $2 \mathrm{~cm}(\mathrm{~K} 2)$

Dalam aturan TCFFHR 2016, jika robot melakukan kontak dengan dinding dan mengakibatkan goresan pada dinding dengan panjang goresan lebih dari $2 \mathrm{~cm}$ maka akan dikenakan pinalti. Maka jika robot tidak menggores dinding maka navigasi dianggap berhasil.

3. Jumlah putaran dalam 3 menit (P)

Semakin banyak putaran yang dapat dilakukan robot, maka kehandalan navigasi akan semakin baik.

4. Apakah semua ruangan terjelajahi dalam waktu kurang dari 3 menit? (TR)

Jika terjelajahi semua maka akan terisi "Ya" dan jika tidak terjelajahi semua akan terisi "Tidak. Selama bernavigasi, robot harus dapat mejelajahi semua ruangan dalam peta pengujian.

5. Apakah sebelum 3 menit robot terjebak ? (TJ)

Jika terjebak maka akan terisi "Ya" dan jika tidak terjebak akan terisi "Tidak". Kondisi robot yang terjebak akan sangat merugikan dalam perlombaan. Definisi terjebak disini adalah robot tidak bergerak atau melakukan gerakan yang sama terus menerus pada sebuah tempat.

Hasil dari pengujian ini dapat dilihat pada Tabel VII dan Tabel VIII, terlihat bahwa navigasi robot yang menggunakan logika fuzzy memiliki peforma yang lebih baik dibandingkan metode kontrol Propotional Derivative (PD).

TABEL VII

Perbandingan Nilai Rata-RAta PARAmeter Pengujian Navigasi FOLLOW KANAN

\begin{tabular}{|l|c|c|}
\hline & Metode PD & Metode Fuzzy \\
\hline K (kontak/putaran) & 2.367 & 0,66 \\
\hline K2 (kontak/putaran) & 0 & 0 \\
\hline P (putaran) & 4.9475 & 5,5 \\
\hline TR & Ya & Ya \\
\hline TJ (kali terjebak) & 2 & 0 \\
\hline
\end{tabular}

TABEL VIII

Perbandingan Nilai Rata-Rata Parameter Pengujian Navigasi FOLLOW KIRI

\begin{tabular}{|l|c|c|}
\hline & Metode PD & Metode Fuzzy \\
\hline K (kontak/putaran) & 3,16 & 1,75 \\
\hline K2 (kontak/putaran) & 0 & 0 \\
\hline P (putaran) & 4.91 & 5,5 \\
\hline TR & Ya & Ya \\
\hline TJ (kali terjebak) & 3 & 0 \\
\hline
\end{tabular}

\section{Pengujian Pergerakan Robot Menuju Set Point}

Pengujian selanjutnya adalah menguji navigasi robot pada lintasan lurus untuk melihat pola gerakan robot dan waktu yang diperlukan untuk menuju setpoint. Robot ini diharapkan mampu melakukan navigasi pada lintasan lurus dengan jarak 
Teknologi Elektro, Vol. 16, No. 02, Mei - Agustus 2017

$10 \mathrm{~cm}$ dari tembok lapangan. Variasi pengujian dilakukan dengan memberikan offset pada kondisi start awal robot sebelum bernavigasi, yaitu pada $20 \mathrm{~cm}$ jarak badan robot dari tembok (setpoint $+10 \mathrm{~cm}$ ) dan $0 \mathrm{~cm}$ (setpoint $-10 \mathrm{~cm})$ seperti yang terlihat pada Gambar 9. Tabel IX menunjukkan waktu rata-rata menuju steady state dengan offset awal $0 \mathrm{~cm}$ dan 20 $\mathrm{cm}$. Terlihat bahwa saat bernavigasi,robot mencapai steady state sesuai dengan setpoint yaitu $10 \mathrm{~cm}$ dengan waktu ratarata 2,9 detik. Dalam metode kontrol logika fuzzy, untuk meningkatkan respons robot terhadap error dapat dilakukan dengan merancang fungsi keanggotaan input di mana transisi antar himpunan dibuat curam (meningkatkan kemiringan slope).

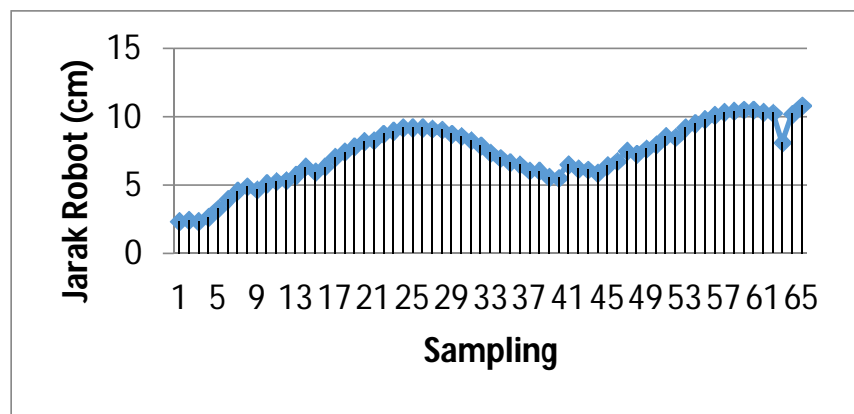

(a)

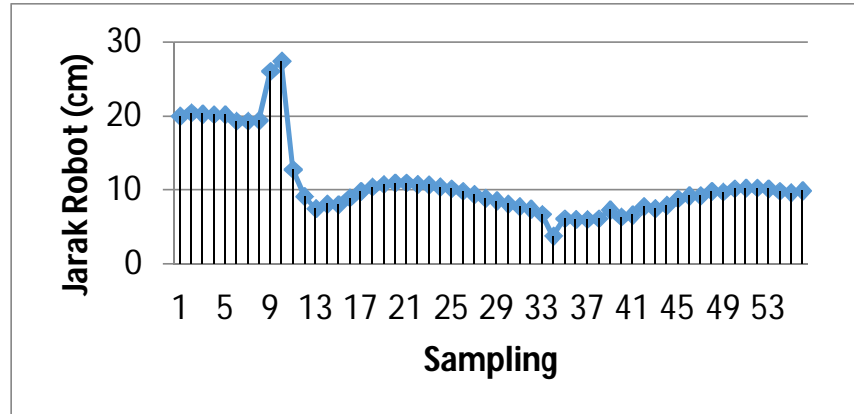

(b)

Gambar 9: Jarak robot ke dinding ketika robot bernavigasi dengan posisi start (a) $0 \mathrm{~cm}$ dan (b) $20 \mathrm{~cm}$

TABEL IX

WAKTU RATA-RATA MENUJU STEADY STATE DARI OFFSET 0 CM DAN 20 CM

\begin{tabular}{|l|c|}
\hline \multicolumn{1}{|c|}{ Mode Navigasi } & Waktu yang diperlukan \\
\hline Follow kanan $(0 \mathrm{~cm})$ & $3,316 \mathrm{sec}$ \\
\hline Follow kanan $(20 \mathrm{~cm})$ & $4,35 \mathrm{sec}$ \\
\hline Follow kiri $(0 \mathrm{~cm})$ & $2,066 \mathrm{Sec}$ \\
\hline Follow kiri $(20 \mathrm{~cm})$ & $2,116 \mathrm{Sec}$ \\
\hline
\end{tabular}

\section{KESIMPULAN}

Navigasi robot yang berbasis kendali logika fuzzy telah berhasil direalisasikan. Dalam melakukan navigasi menjelajahi peta lapangan selama 3 menit, rasio kontak dengan dinding dengan jumlah putaran untuk follow kanan

Gunawan Dewantoro: Implementasi Pengendali Logika Fuzzy... yaitu kurang dari 1 kontak/putaran sedangkan untuk follow kiri rasio kurang dari 2 kontak/putaran. Robot dapat menjelajahi semua ruangan tanpa terjebak dan tanpa mengakibatkan goresan yang panjangnya lebih dari $2 \mathrm{~cm}$ pada dinding. Dalam waktu 3 menit jumlah putaran minimal mengelilingi lapangan yang dapat dilakukan robot adalah 5 kali putaran. Dalam bernavigasi ketika robot mencapai steady state sesuai dengan setpoint yaitu $10 \mathrm{~cm}$ dengan waktu ratarata 2,9 detik. Dari hasil pengujian, metode ini dapat mengurangi jumlah kontak per putaran dibandingkan metode PD.

\section{UCAPAN TERIMA KASIH}

Penulis mengucapkan terima kasih kepada DRPM Dikti pada skema Penelitian Dosen Pemula 2015 atas segala dukungan yang diberikan.

\section{REFERENSI}

[1] D. Hanafi, M. Fauzi, dan M. Yusof, Wall Follower Autonomus Robot Development Applaying Fuzzy Incremental Controller, Intelligent Control and Automation, vol.4, hal. 18-25, 2013.

[2] A. Ilyas, S. Jahan, dan M. Ayyub, Tuning Of Conventional PID and Fuzzy Logic Control Using Different Defuzzification Technique, International Journal of Scientific \& Technology Research, vol.2 (1), Jan. 2013.

[3] V. M. Peri dan D. Simon, Fuzzy logic control for an autonomous robot, Proc. NAFIPS 2005, hal. $337-342$.

[4] G. Dewantoro dan Y. L. Kuo. Robust speed-controlled permanent magnet synchronous motor drive using fuzzy logic controller, Proc. FUZZ-IEEE 2011, hal. 884-888.

[5] Y. Bai, H. Zhuang, D. Advanced Fuzzy Logic Technologies in Industrial Applications. ser. Advances in Industrial Control, Springer, 2006.

[6] M. Hunt dan C. Daly, Autonomous mobile robot navigation using Fuzzy Logic Control, M.Sc. thesis, Dublin City University, Jun. 1998.

[7] I. G. M. W. Meindra, R. S. Hartati, Linawati. Peramalan beban listrik harian dengan metode Adaptive Neuro Fuzzy Inference System. Majalah Ilmiah Teknologi Elektro vol. 13 (1), Jan. 2014.

[8] A. Septiaji, I. Setiawan, dan Darjat. Perancangan robot mobil penjejak dinding koridor menggunakan kendali logika fuzzy, M.T. thesis, Universitas Diponegoro, Indonesia, 2011.

[9] N. K. Ariasih, I. P. A. Bayupati, dan I. K. Gede. Sistem pendukung pemilihan lokasi TPA sampah menggunakan metode min_max inference fuzzy. Majalah Ilmiah Teknologi Elektro vol. 14 (1), Jan. 2015. 